\author{
ANDRZEJ TWARDOWSKI \\ Uniwersytet im. Adama Mickiewicza \\ w Poznaniu
}

\title{
ROLA RÓWIEŚNICZEGO TUTORINGU W EDUKACJI INKLUZYJNEJ UCZNIÓW Z NIEPEŁNOSPRAWNOŚCIAMI
}

\begin{abstract}
Twardowski Andrzej, Rola rówieśniczego tutoringu w edukacji inkluzyjnej uczniów z niepełnosprawnościami [The Role of Peer Tutoring in Inclusive Education of Students with Disabilities]. Studia Edukacyjne nr 50, 2018, Poznań 2018, pp. 31-44. Adam Mickiewicz University Press. ISSN 1233-6688. DOI: $10.14746 /$ se.2018.50.2
\end{abstract}

Researchers and teachers are interested in implementing best practices that improve inclusion of students with disabilities in ordinary schools. One solution to overcome these challenges is the implementation of peer tutoring as a flexible, peer-mediated strategy that involves students serving as academic tutors and tutees. In this article the author analyzes the following issues: 1) genesis and essence of inclusive education, 2) theoretical basis of peer tutoring, 3) peer tutoring in dyads, 4) peer tutoring in classroom, and 5) conditions for implementing peer tutoring.

Key words: inclusive education, students with disabilities, peer tutoring, tutors and tutees

\section{Wstęp}

Edukacja w tradycyjnej szkole opierała się na z gruntu fałszywym założeniu o homogeniczności grup uczniów znajdujących się w poszczególnych klasach. W rzeczywistości uczniowie, pomimo że są w tym samym wieku, różnią się pod względem kondycji fizycznej, poziomu inteligencji, zainteresowań, uzdolnień, sprawności w wykonywaniu różnych działań i tym podobnych. Różnią się indywidualnymi profilami rozwoju. Każdy ma charakterystyczne dla siebie mocne strony, ale w pewnych sferach i aspektach funkcjonowania wymaga dodatkowego wsparcia ${ }^{1}$. Ten oczywisty fakt uwzględnia idea edu-

${ }^{1}$ Podjęty przeze mnie problem ma szerszy kontekst. Mianowicie, brak poszanowania dla różnorodności uczniów w tradycyjnym modelu edukacji przyczynia się do nasilenia procesów 
kacji inkluzyjnej, w której przyjmuje się, że grupy uczniowskie są z natury heterogeniczne. Zwolennicy edukacji inkluzyjnej akcentują konieczność poszanowania różnic między dziećmi i uwzględnienia ich w procesie edukacji.

\section{Geneza i istota edukacji inkluzyjnej}

Dokumentem, który zapoczątkował upowszechnianie się idei edukacji inkluzyjnej (włączającej) była Deklaracja z Salamanki oraz wytyczne dla działań w zakresie specjalnych potrzeb edukacyjnych, przyjęte przez Światową Konferencję Dotyczącą Specjalnych Potrzeb Edukacyjnych: Dostęp i Jakość, zorganizowaną przez UNESCO w dniach 7-10.06.1994 roku. W „Wytycznych dla działań..." zamieszczono następujący zapis:

szkoły powinny przyjmować wszystkie dzieci niezależnie od ich warunków fizycznych, intelektualnych, socjalnych, emocjonalnych, językowych czy innych. Dotyczy to dzieci upośledzonych i utalentowanych, dzieci ulicy i dzieci pracujących, dzieci ze społeczności koczowniczych czy odległych, dzieci z mniejszości językowych, etnicznych czy kulturowych oraz dzieci z innych regionów lub grup nierównych szans czy z marginesu (...) Szkoły muszą znaleźć sposoby skutecznego kształcenia wszystkich dzieci, także tych, które znajdują się w wyjątkowo niekorzystnej sytuacji czy są dotknięte poważnym kalectwem².

Początkowo pojęcie inkluzji w edukacji było utożsamiane z włączaniem w nurt szkolnictwa ogólnodostępnego uczniów z niepełnosprawnością. Z czasem definicję poszerzono i w roku 1994, w dokumentach UNESCO, wyrażono ją następująco:

edukacja włączająca jest nieustannie trwającym procesem ukierunkowanym na oferowanie wysokiej jakości edukacji dla wszystkich oraz poszanowanie różnorodności, różnych potrzeb i zdolności, właściwości i oczekiwań uczniów i społeczności, eliminującym wszelkie formy dyskryminacji ${ }^{3}$.

A zatem, edukacja inkluzyjna powinna stwarzać równe szanse wszystkim uczniom, bez względu na ich pochodzenie, rodzaj niepełnosprawności, przystosowanie społeczne, rasę, czy światopogląd. Celem edukacji inkluzyjnej jest zredukowanie, a w dalszej perspektywie wyeliminowanie kształcenia segre-

społecznej stratyfikacji. Szerzej na ten temat: Z. Melosik, Edukacja a stratyfikacja społeczna, [w:] Pedagogika, t. 2, red. Z. Kwieciński, B. Śliwerski, Warszawa 2008, s. 328-366.

2 Deklaracja z Salamanki oraz wytyczne dla działań w zakresie specjalnych potrzeb edukacyjnych, https://rownosc.info/media/uploads/deklaracja_z_salamanki.pdf, [dostęp: 25.10.2018].

${ }^{3}$ B. Papuda-Dolińska, Realizacja koncepcji inkluzyjnej edukacji w szkołach planu jenajskiego doświadczenia holenderskie, [w:] Podmiotowość w edukacji wobec odmienności kulturowych oraz spotecznych zróżnicowań, red. N. Starik, A. Zduniak, Poznań 2012, s. 427. 
gacyjnego uczniów ze specjalnymi potrzebami edukacyjnymi poprzez: (1) dostępność kształcenia w szkołach ogólnokształcących dla wszystkich dzieci, (2) umożliwienie pobierania nauki przez uczniów niepełnosprawnych w szkołach rejonowych oraz (3) uczenie według wspólnego programu kształcenia oraz z wykorzystaniem tej samej ścieżki edukacyjnej, opartej na podobnych treściach nauczania ${ }^{4}$. Aby osiągnąć wymienione cele, nie wystarczy umieścić wszystkie dzieci ze specjalnymi potrzebami edukacyjnymi w szkołach ogólnodostępnych. Konieczne jest wprowadzenie takich zmian w funkcjonowaniu tych szkól, aby stwarzały możliwość wszechstronnego rozwoju wszystkim uczącym się.

W edukacji inkluzyjnej dzieci ze specjalnymi potrzebami edukacyjnymi otrzymują dodatkową pomoc, jednak nie w formie odrębnego programu nauczania, ale w ramach programu normalnego, odpowiadającego zróżnicowanym potrzebom dzieci w danej klasie. Podstawową zasadą edukacji inkluzyjnej jest stworzenie wszystkim dzieciom możliwości wspólnego uczenia się, niezależnie od dzielących je różnic.

Zadaniem szkół inkluzyjnych jest określenie indywidualnych potrzeb uczniów oraz dążenie do tego, aby im sprostać. Należy też wziąć pod uwagę różnice w stylach uczenia się dzieci i tempie ich pracy ${ }^{5}$.

Edukacja inkluzyjna sprzyja przezwyciężaniu biedy i wykluczenia społecznego, poprawie jakości edukacji dla wszystkich oraz zwalczaniu dyskryminacji.

\section{Teoretyczne podstawy rówieśniczego tutoringu}

Edukacja inkluzyjna wymaga stworzenia dzieciom możliwości wspólnego uczenia się, niezależnie od dzielących je różnic. Wymaga to od nauczycieli poszukiwania nowych sposobów nauczania. W klasach inkluzyjnych często stosowany jest tak zwany rówieśniczy tutoring (Peer Tutoring). Jest to alternatywna w stosunku do tradycyjnych metoda nauczania, polegająca na tym, że uczniowie podejmują rolę nauczycieli swych kolegów w klasie lub poza nią. Zazwyczaj uczniowie pracują w parach (diadach) lub małych grupach, ale można stosować tę metodę również w pracy z całą klasą.

Teoretyczne uzasadnienie dla stosowania rówieśniczego tutoringu w edukacji inkluzyjnej można znaleźć w koncepcjach rozwoju psychicznego

${ }^{4}$ G. Szumski, Edukacja inkluzyjna - geneza, istota, perspektywy, Kwartalnik Pedagogiczny, 2006, 1, s. 93-114.

${ }^{5}$ T. Zacharuk, Edukacja włączająca szansą dla wszystkich uczniów, Meritum. Mazowiecki Kwartalnik Edukacyjny, 2011, 1, s. 5. 
Lwa Wygotskiego i Jeana Piageta. Pierwszy wymieniony autor analizował sposoby, za pomocą których bardziej dojrzali uczestnicy kultury przekazują dzieciom wypracowane $\mathrm{w}$ toku historii społeczeństwa sposoby działania z użyciem narzędzi i znaków. Zdaniem Lwa Wygotskiego, rozwój psychiczny dziecka może dokonywać się w relacji z kimś, kto wie więcej o tych sposobach i narzędziach, czyli z dorosłym lub bardziej kompetentnym rówieśnikiem. Wszystkie umiejętności i wiedza najpierw są doświadczane w procesie interakcji społecznej, a dopiero później zostają zinterioryzowane i podlegają dekontekstualizacji.

Każda z wyższych funkcji psychicznych była dlatego zewnętrzna, że była funkcją społeczną, zanim stała się wewnętrzna; zanim stała się funkcją ściśle psychiczną, była poprzednio stosunkiem społecznym dwojga ludzi ${ }^{6}$.

Bez pośrednictwa i pomocy bardziej kompetentnych partnerów dziecko nie byłoby w stanie rozwinąć swoich procesów poznawczych, ani wytworzyć poznawczej reprezentacji siebie i otaczającej rzeczywistości. Proces interioryzacji przebiega stopniowo. Najpierw tutor (dorosły lub bardziej kompetentny rówieśnik) kontroluje i ukierunkowuje aktywność dziecka, ale stopniowo obydwie strony dochodzą do „podzielania” czynności i wspólnego rozwiązywania problemów. Następnie inicjatywę przejmuje dziecko, a tutor pomaga wówczas, kiedy napotyka ono na trudności. Wreszcie tutor pozwala dziecku działać samodzielnie, a sam występuje w roli przychylnego, jednoosobowego audytorium. W koncepcji Lwa Wygotskiego, nauczający partnerzy nie są równi dziecku, przy czym nierówność dotyczy rozumienia, a nie władzy.

Z tego powodu zarówno dorośli, jak i rówieśnicy mogą przyczynić się do rozwoju poznawczego dziecka w toku interakcji. Aby jednak rozwój ten mógł zachodzić podczas interakcji rówieśniczej, konieczny jest wyższy stopień przygotowania któregoś z partnerów ${ }^{7}$.

Odmienny pogląd na rolę rówieśników w procesie rozwoju psychicznego dziecka zaprezentował Jean Piaget. Jego zdaniem, kontakty z rówieśnikami $\mathrm{w}$ okresie przedoperacyjnym sprzyjają przezwyciężeniu egocentryzmu, ponieważ skłaniają dzieci do porównywania swoich perspektyw poznawczych. Autor podkreślał, że interakcja dziecka z dorosłym jest asymetryczna, ponieważ dorosły ma większą wiedzę i władzę, a to narusza warunek wzajemności niezbędny do osiągnięcia zrównoważenia struktur poznawczych. Kiedy

${ }^{6}$ L.S. Wygotski, Wybrane prace psychologiczne, Warszawa 1971, s. 132-133.

7 J. Tudge, B. Rogoff, Wptyw rówieśników na rozwój poznawczy - podejście Piageta i Wygotskiego, [w:] Dziecko wśród rówieśników i dorostych, red. A. Brzezińska, G. Lutomski, B. Smykowski, Poznań 1995, s. 181. 
punkt widzenia dorosłego dominuje, dziecko porzuca swoje pomysły, często jeszcze słabo skrystalizowane i nie mogące konkurować z pomysłami dorosłego $^{8}$. Ale kiedy dziecko zgadza się z rozwiązaniami proponowanymi przez dorosłego, to nie uczy się do nich samodzielnie dochodzić. Zatem, podzielanie punktu widzenia dorosłego nie zmusza dziecka do poznawczych restrukturyzacji, a co za tym idzie - nie stymuluje jego rozwoju umysłowego. Inaczej jest $\mathrm{w}$ relacjach $\mathrm{z}$ rówieśnikami, ponieważ charakteryzują się równowagą zdolności poznawczych i władzy. Kiedy partner ma odmienne zdanie, dziecko dąży do wyjaśnienia swojego punktu widzenia poprzez skonfrontowanie go z punktem widzenia partnera. $W$ takiej sytuacji konieczna jest poznawcza rekonstrukcja, ponieważ dziecko musi powiązać ideę przedstawioną przez partnera z własnym pomysłem. Pojawienie się konfliktu między perspektywą własną a perspektywą partnera zmusza dziecko do przekształcenia dotychczasowej reprezentacji poznawczej. W konsekwencji dziecko zdobywa nową wiedzą, która nie jest prostą sumą informacji posiadanych przez nie i partnera, ale bardziej złożona ${ }^{9}$. Oznacza to, że interakcje z rówieśnikami stają się źródłem postępu w rozwoju poznawczym dzięki temu, że prowadzą do konfliktów społeczno-poznawczych.

Oczywiście konflikt społeczno-poznawczy sam z siebie nie tworzy nowych form operacji umysłowych, natomiast doprowadza do utraty równowagi, co z kolei wyzwala aktywność poznawczą. Konflikt społeczno-poznawczy działa jak katalizator w reakcji chemicznej: choć nie jest obecny w końcowym produkcie, to jest niezbędny, aby reakcja mogła nastąpić ${ }^{10}$.

A zatem, kontakty z rówieśnikami wywołują konflikty społeczno-poznawcze i zmuszają do ich rozwiązywania. Tym samym, skłaniają partnerów do intelektualnej współpracy i przyczyniają się do postępu w rozwoju umysłowym ${ }^{11}$.

\section{Rówieśniczy tutoring $\mathrm{w}$ diadach}

Można wyróżnić trzy rodzaje interakcji o charakterze nauczającym, zachodzących w diadzie: uczenie przez rówieśnika, uczenie się z rówieśnikiem

\footnotetext{
${ }^{8}$ A. Twardowski, Rola rówieśniczego tutoringu w rozwijaniu umiejętności komunikacyjnych dzieci przedszkolnych z niepetnosprawnościami, Interdyscyplinarne Konteksty Pedagogiki Specjalnej 2016, 15, s. 47.

${ }^{9}$ W. Doise, The development of individual competencies through social interactions, [w:] Children helping children, red. H.C. Foot, M.J. Morgan. R.H. Shute, New York 1990, s. 376.

10 A.-N. Perret-Clermont, Social interaction and cognitive development in children, London 1980, s. 178 .

11 A. Twardowski, Możliwości wykorzystania rówieśniczego tutoringu w edukacji dzieci z niepetnosprawnościa intelektualna, Interdyscyplinarne Konteksty Pedagogiki Specjalnej, 2014, 5, s. 20.
} 
oraz wzajemny rówieśniczy tutoring. Wymienione rodzaje tutoringu są zazwyczaj stosowane w ramach zajęć pozalekcyjnych - korekcyjno-wyrównawczych lub terapeutycznych, albo podczas zajęć w świetlicy szkolnej. Możliwe jest też stosowanie tutoringu w diadach podczas lekcji w tak zwanej „małej klasie”, liczących nie więcej niż dziesięcioro uczniów. O doborze par oraz który uczeń wystąpi w roli tutora decyduje nauczyciel.

Często wykorzystywanym typem rówieśniczego tutoringu w diadzie jest „uczenie przez rówieśnika” (Cross-age Peer Tutoring). Termin ten opisuje sytuację, w której jedno dziecko (tutor) pomaga drugiemu (uczniowi, nowicjuszowi) opanować określone wiadomości i umiejętności poprzez dostarczanie wskazówek i porad lub bezpośrednie kierowanie czynnościami partnera. Tutor jest starszy od ucznia o dwa lata lub więcej i przewyższa ucznia poziomem wiedzy oraz umiejętności. Obydwaj mają świadomość, kto jest ekspertem, czyli tym, kto uczy, a kto nowicjuszem, czyli tym, który się uczy. Relacja między dziećmi ma charakter asymetryczny. Tutor dostarcza informacji i instrukcji oraz kieruje wysiłkami ucznia zmierzającymi do rozwiązania określonego zadania. Tutor i uczeń nie zamieniają się rolami. Szczególną odmianą uczenia przez rówieśnika jest tak zwany "tutoring z odwróconymi rolami” (Reverse-Role Tutoring), polegający na tym, że starszy uczeń z niepełnosprawnością uczy młodszego i mniej kompetentnego pełnosprawnego rówieśnika ${ }^{12}$. Ta forma tutoringu jest stosowana na zajęciach pozalekcyjnych. Zadaniem tutora jest udzielenie pomocy partnerowi w opanowaniu materiału nauczania oraz nabyciu określonych umiejętności interpersonalnych. Teoretycznych podstaw dla uczenia przez rówieśnika dostarcza koncepcja Lwa Wygotskiego oraz prace jego kontynuatorów, między innymi: Jerome Brunera, Davida Wooda oraz Jamesa Wertscha.

Drugim typem rówieśniczego tutoringu w diadzie jest uczenie się z rówieśnikiem (Same-age Peer Tutoring). Podany termin opisuje sytuację, w której dwoje dzieci, w tym samym lub podobnym wieku i o podobnym poziomie zdolności, próbuje rozwiązać określone zadanie. W tym celu wymieniają się informacjami. Wiedza, jaką dysponuje każde z dzieci jest niepełna i dlatego żadne nie potrafi rozwiązać zadania samodzielnie. Natomiast, mogą je rozwiązać we współpracy wymieniając się posiadanymi informacjami i pomagając sobie w zdobywaniu nowych. Jest to uczenie się poprzez wspólne odkrywanie. Dokonuje się w ramach symetrycznej relacji, w atmosferze wzajemnej sympatii i przy równym zaangażowaniu obojga partnerów. Dzieci mogą wymieniać się rolami tutora i ucznia. Teoretycznego uzasadnienia dla uczenia się z rówieśnikiem dostarcza piagetowska teoria rozwoju poznawczego oraz

12 L. Shisler, R.T. Osguthorpe, W.D. Eiserman, The effects of reverse-role tutoring on the social acceptance of students with behavioral disorders, Behavioral Disorders, 1987, 1, s. 35-44. 
prace Willema Doise, Gabriela Mugny i Anne-Nelly Perret-Clermont z Uniwersytetu Genewskiego.

Wzajemny rówieśniczy tutoring (Reciprocal Peer Tutoring) to trzeci typ nauczającej interakcji w diadzie. Przy czym, wzajemne uczenie może być prowadzone zarówno w pojedynczej diadzie, jak i w grupie podzielonej na kilka diad. Poziomy kompetencji tutora i ucznia powinny być podobne. Co pewien czas, na przykład co 10 minut, członkowie diady wymieniają się rolami. Wzajemne uczenie się przebiega według z góry założonego planu. Uczestnicy zajęć uczą jeden drugiego - podpowiadają sobie, monitorują swoje działania, nawzajem się oceniają i motywują ${ }^{13}$. Tutorzy przygotowują pomoce dydaktyczne i otrzymują informacje zwrotne od uczniów. Dzięki temu są bardziej zaangażowani $\mathrm{w}$ proces kształcenia. Uczniowie wybierają z listy przygotowanej przez nauczyciela zadania, a także nagrody za poprawne wykonanie zadań. Wielokrotna zamiana ról, charakterystyczna dla omawianej formy rówieśniczego tutoringu, jest bardzo korzystna, ponieważ wszyscy uczniowie mają możliwość sprawdzenia się zarówno w roli turora, jak i nowicjusza. Zamiany ról powodują, że uczniowie są częściej nagradzani i stają się bardziej współzależni. To zaś sprzyja budowaniu atmosfery współpracy i zwiększa motywację do nauki.

\section{Rówieśniczy tutoring w klasie szkolnej}

Edukacja inkluzyjna, jak wspomniano, wymaga stworzenia dzieciom możliwości wspólnego uczenia się, niezależnie od dzielących je różnic. Wymaga to od nauczyciela poradzenia sobie z nowymi problemami. Na przykład, musi on rozstrzygnąć, jak jednocześnie nauczać dzieci, które dobrze czytają i takie, które nie czytają w ogóle. Albo, jak zorganizować lekcję, kiedy część dzieci uczy się szybko i łatwo, a część wymaga dodatkowych wskazówek, powtórzeń i instrukcji? Wreszcie, musi zdecydować, czy dotychczas stosowane metody nauczania będą skuteczne w klasach inkluzyjnych, z natury heterogenicznych, czy też powinien poszukiwać nowych?

Pomocne $w$ rozstrzygnięciu tych dylematów mogą być trzy formy rówieśniczego tutoringu, możliwe do stosowania z całą klasą. Pierwszą z nich jest wspólne uczenie się (Cooperative Learning). Jest to optymalny sposób nauczania dzieci o zróżnicowanym poziomie zdolności. Bardzo dobrym przykładem wspólnego uczenia sięjest tak zwana „Układanka” (Jigsaw), opracowana przez Eliota Aronsona. Nauczyciel rozdziela materiał nauczania na pięć do sześciu

${ }_{13}$ M. Ginsburg-Block, J. Fantuzzo, Reciprocal peer tutoring: An analysis of "teacher" and "student" interactions as a function of training and experience, School Psychology Quarterly, 1997, 2, s. 134-149. 
części. Następnie dzieli klasę na 5 lub 6-osobowe zespoły, dbając, aby każdy zespół składał się z uczniów o różnym poziomie zdolności. Poszczególnym członkom każdego zespołu przekazuje fragmenty nauczanego materiału. W rezultacie wszyscy uczniowie stają się ekspertami odpowiedzialnymi za opanowanie określonej części wiedzy, a następnie przekazanie jej pozostałym członkom zespołu. Uczniowie, którym przydzielono te same fragmenty materiału spotykają się w tak zwanych "grupach eksperckich”. Analizują otrzymany materiał, identyfikują jego najważniejsze elementy, dyskutują i uczą się go. Następnie wracają do swoich zespołów i przekazują kolegom opanowaną wiedzę. W metodzie tej wszyscy członkowie zespołu są odpowiedzialni za uczenie pozostałych i wszyscy muszą uczyć się od siebie nawzajem. Jednak, co najważniejsze, „dzieci uczą się, że żadne z nich nie może osiągnąć dobrego wyniku bez pomocy wszystkich członków zespołu - i że każdy jego członek wnosi od siebie coś szczególnego i ważnego"14.

Bardzo przydatny w edukacji inkluzyjnej jest rówieśniczy tutoring w całej klasie (ClassWide Tutoring). Ta forma tutoringu została opracowana przez Josepha Delquadri i jego współpracowników na Uniwersytecie w Kansas, w ramach Juniper Gardens Children's Project. Celem projektu było zwiększenie ilości czasu spędzanego przez uczniów na wykonywaniu zadań związanych z uczeniem się. Głównie chodziło o zwiększenie: tempa nauczania, zakresu opanowanego materiału, rozumienia materiału, częstości korekt popełnionych błędów oraz liczby informacji zwrotnych ${ }^{15}$. Można wskazać na pięć głównych cech tutoringu rówieśniczego w całej klasie. Po pierwsze, wszyscy uczniowie są łączeni w pary. Po drugie, uczniowie są szkoleni, jak mają podpowiadać partnerowi, poprawiać jego błędy oraz dostarczać mu informacji zwrotnych. Po trzecie, między tutorami i nowicjuszami zachodzą częste interakcje werbalne, co zwiększa szanse obu stron na dzielenie się wiedzą. Po czwarte, role w diadzie są wymienne, czyli w trakcie sesji każdy uczeń występuje zarówno w roli tutora, jak i nowicjusza. Po piąte, tutoring rówieśniczy w całej klasie składa się z zestawu ustrukturyzowanych działań, które uczniowie powinni samodzielnie wykonywać.

Nauczyciel łączy uczniów w diady, które następnie są przydzielane do dwóch równolicznych drużyn, podobnych pod względem poziomu zdolności i osiągnięć szkolnych. W klasach od drugiej do szóstej sesje rówieśniczego tutoringu trwają 35 minut i są przeprowadzane trzy razy w tygodniu. Na początku sesji, w każdej diadzie, jeden z uczniów podejmuje rolę tutora i naucza swego kolegę, zgodnie z wcześniej ustalonym planem. Po upływie

${ }^{14}$ E. Aronson, Terapia dla rywalizującego społeczeństwa, [w:] Psychologia i życie, red. P.G. Zimbardo, F.L. Ruch, Warszawa 1988, s. 529.

${ }^{15}$ C.R. Greenwood, J.C. Delquadri, R.V. Hall, Longitudinal effects of classwide peer tutoring, Journal of Educational Psychology, 1989, 3, s. 372. 
określonego czasu członkowie diady zamieniają się rolami. Tutorzy uczą swoich partnerów wykonywania różnych zadań szkolnych, takich jak: pisanie zgodne z zasadami ortografii, poprawne rozwiązywanie zadań matematycznych, ciche i głośne czytania ze zrozumieniem, opanowywanie nowych słów, definicji i treści, rozwiązywanie zadań w zeszytach ćwiczeń. Każda diada stara się zdobyć jak najwięcej punktów dla swojej drużyny. Na specjalnej karcie zapisuje punkty uzyskane za poprawnie wykonane zadania. Nauczyciel sprawdza, czy tutorzy i nowicjusze przestrzegają ustalonych zasad oraz czy prawidłowo przydzielają sobie punkty. Pod koniec sesji diady zgłaszają liczbę zdobytych punktów, a nauczyciel je sumuje i ogłasza, która drużyna zwyciężyła w danym dniu.

O skuteczności rówieśniczego tutoringu w całej klasie w dużym stopniu decyduje wykorzystanie formuły gry. Dzieci lubią uczestniczyć w grach i odnosić zwycięstwa. Omawiany rodzaj rówieśniczego tutoringu to umożliwia. Jednakże, warunkiem znalezienia się w gronie zwycięzców jest intensywna współpraca z partnerem w diadzie, polegająca na wzajemnym nauczaniu. Tak zorganizowany tutoring pobudza uczniów do działania, motywuje do uczenia się i eliminuje nudę panującą na tradycyjnych lekcjach.

Aby pracować z bardzo zróżnicowaną grupą uczniów, nauczyciel musi przemyśleć nie tylko jakie metody wykorzysta, ale również czego będzie nauczał. Program nauczania, jeśli ma służyć inkluzyjnej edukacji, musi być zróżnicowany. Nie można stosować tradycyjnej formy nauczania, polegającej na tym, że wszyscy uczniowie wykonują te same zadania, w taki sam sposób i są oceniani według tych samych kryteriów ${ }^{16}$. Nauczyciel musi ustawicznie analizować program nauczania i dążyć do rozstrzygnięcia następujących kwestii: Czego każde dziecko powinno się nauczyć? Jakie elementy lekcji powinny zostać zmienione? Czy uczniowie mogliby uczestniczyć w tej samej formie aktywności na różnych poziomach? Czy mogą wykonywać różne działania, z różnym zaangażowaniem i być oceniani według różnych kryteriów? Nauczyciel może zadawać sobie takie pytania, mając na uwadze tylko jednego niepełnosprawnego ucznia, ale w ostatecznym rozrachunku wypracuje program na tyle elastyczny, że będzie służył całej klasie. Takie możliwości stwarza nauczanie na wielu poziomach (Multi-level Teaching). Przykładem tej formy rówieśniczego tutoringu jest realizacja tematu „Kosmos”17. Uczniom o najwyższym poziomie umiejętności czytania oraz samodzielnego poszukiwania informacji nauczyciel przydzielił zadanie napisania referatu o powsta-

${ }^{16}$ J.S. Thousand, R.A. Villa, A.I. Nevin, Differentiated instruction: Collaborative planning and teaching for universally designed learning, Thousand Oaks 2007, s. 21-24.

17 M. Sapon-Shevin, B. Ayres, J. Duncan, Cooperative learning and inclusion, [w:] Creativity and collaborative learning: A practical guide to empowering students, teachers and families, red. J.S. Thousand, R.A. Villa, A.I. Nevin, Paul Brookes, Baltimore 2002, s. 209-222. 
niu galaktyki. Inni uczniowie byli poproszeni o narysowanie i oznaczenie nazwami planet Układu Słonecznego. Natomiast od dzieci z ograniczonymi możliwościami umysłowymi i językowymi nauczyciel oczekiwał wskazania Słońca, Ziemi i Księżyca znajdujących się w różnym usytuowaniu względem innych planet na schematach Układu Słonecznego. Po przerobieniu tematu, każdy uczeń demonstrował kolegom swoją pracę lub umiejętność. Taki sposób nauczania przynosi korzyści wszystkim uczniom w klasie.

Beverly Rainforth i Judy Kugelmass przytaczają jeszcze inny przykład nauczania na wielu poziomach w klasie składającej się z uczniów o zróżnicowanym poziomie rozwoju umysłowego ${ }^{18}$. Nauczyciel zorganizował sklepik z kanapkami. Uczniowie przyjmowali zamówienia, produkowali i sprzedawali kanapki. Cała klasa była zaangażowana w projekt, ale w różny sposób, stosownie do poziomu posiadanych kompetencji. Niektórzy uczniowie obliczali cenę kanapek, zgodnie z kosztami ich wyprodukowania. Inni obliczali cenę kanapek powiększoną o podatek. Jeszcze inni dokonywali rzeczywistych zakupów składników potrzebnych do wyprodukowania kanapek. Byli też uczniowie, którym powierzono wykonanie plakatu reklamowego oraz opracowanie miesięcznego sprawozdania finansowego. Natomiast uczniowie, których Indywidualne Programy Edukacyjno-Terapeutyczne przewidywały kształcenie praktycznych umiejętności życiowych przygotowywali kanapki. Przedstawiony projekt umożliwił włączenie się we wspólne działanie wszystkim uczniom w klasie oraz pozwolił zaspokoić potrzeby edukacyjne uczniów w optymalny sposób.

\section{Uwarunkowania skuteczności rówieśniczego tutoringu w edukacji inkluzyjnej}

Podstawowym celem edukacji inkluzyjnej jest stworzenie możliwości wspólnego uczenia się wszystkim dzieciom, niezależnie od dzielących je różnic. Aby ten cel osiągnąć, nauczyciele muszą stwarzać warunki sprzyjające uczeniu się we współpracy i przy pomocy rówieśników. Przede wszystkim muszą: rozwijać umiejętności społeczne uczniów, budować atmosferę współpracy w klasie, kształtować u uczniów proinkluzyjne postawy oraz eliminować stygmatyzujący język.

Wśród umiejętności społecznych szczególną rolę odgrywa sposób spostrzegania siebie i innych. Dlatego, nauczyciel powinien zachęcać uczniów do zastanawiania się nad następującymi kwestiami: (1) jakie trzy rzeczy robię naprawdę dobrze; (2) z wykonaniem jakich trzech rzeczy mam problem;

${ }_{18}$ B. Rainforth, J.W. Kugelmass, Curriculum and instruction for all learners: Blending systematic and constructivist approaches in inclusive elementary schools, Baltimore 2003, s. 56-61. 
(3) w jaki sposób mogę pomóc innym oraz (4) w jakich sprawach potrzebuję pomocy i jaka pomoc jest mi potrzebna. Udzielenie odpowiedzi na te pytania uzmysławia uczniom, że każdy ma określone zalety i możliwości, ale jednocześnie każdy ma pewne niedostatki i w pewnych dziedzinach potrzebuje pomocy. Takie działanie pomaga uczniom spostrzegać się nawzajem w sposób wielowymiarowy oraz promuje szacunek wobec innych. W konsekwencji, sprzyja przekształcaniu się klasy we wzajemnie wspierającą się wspólnotę.

Rówieśniczy tutoring można z powodzeniem stosować wówczas, kiedy w klasie panuje atmosfera współpracy. Dlatego, tak ważne jest eliminowanie działań napędzających rywalizację między dziećmi ${ }^{19}$. Takimi działaniami jest zamieszczanie wyników różnych rankingów na tablicach ogłoszeń i klasowych gazetkach, konkursy na najlepszego matematyka w klasie, czy najlepsze wypracowanie, nagrody dla najlepszej drużyny, wręczanie dyplomów, nagród i odznaczeń uczniom osiągającym najlepsze wyniki z różnych przedmiotów. Byłoby lepiej, gdyby wszyscy uczniowie mogli znaleźć się na szkolnych i klasowych tablicach ogłoszeń. Należy zauważać i doceniać sukcesy nie tylko najlepszych uczniów, ale również tych, których możliwości są ograniczone, czasami znacznie. Należy pozwolić, aby uczniowie sami decydowali, kogo wyróżnić, kto zasłużył na nagrodę, ponieważ osiągnął znaczny postęp, czyj rysunek umieścić na klasowej gazetce, czyje wypracowanie przeczytać, kogo pochwalić, komu wręczyć dyplom lub odznakę. Ale unikanie negatywnych porównań to za mało. Nauczyciel musi znajdować lub stwarzać okazje do rozmawiania z uczniami o różnicach, wyjaśniać im, że różnice są naturalnym zjawiskiem i nie przesądzają o wartości człowieka. Niektórzy nauczyciele błędnie sądzą, że jeśli nie będą rozmawiać z dziećmi o występujących między nimi różnicach, to ograniczą ich tendencje do wzajemnego porównywania się i oceniania, budujących atmosferę rywalizacji. W rzeczywistości jest na odwrót. Jeśli nauczyciel konsekwentnie unika tematu różnic w zdolnościach i umiejętnościach uczniów, wówczas otrzymują oni komunikat, że o pewnych rzeczach nie można mówić i dyskutować. $W$ rezultacie, poziom emocjonalnego dyskomfortu u uczniów wzrasta.

Niewątpliwie, uczniowie powinni wiedzieć, w jaki sposób różnią się pod względem zdolności, umiejętności i zainteresowań. Należy jednak zaznaczyć, że równie ważne jest rozmawianie z uczniami o łączących ich podobieństwach. Podkreślanie różnic bez zwracania uwagi na podobieństwa może prowadzić do ukształtowania się u uczniów przekonania, że nie ma płaszczyzny do budowania wzajemnych relacji. Dlatego, rozmowy nauczyciela z uczniami o różnicach muszą być równoważone rozmowami o podobień-

${ }_{19}$ M. Sapon-Shevin, Because we can change the world: A practical guide to building cooperative, inclusive school communities, Boston 1999, s. 37. 
stwach. O tym, że wszyscy uczniowie przychodzą do szkoły, aby się uczyć, że każdy pewne rzeczy robi lepiej, a inne gorzej, ale wszyscy mogą osiągnąć lepsze wyniki, jeśli będą współpracować i nawzajem sobie pomagać ${ }^{20}$.

Istotny warunek skuteczności rówieśniczego tutoringu stanowi kształtowanie u uczniów proinkluzyjnych postaw. Ważny jest sposób, w jaki nauczyciel rozmawia z uczniami o różnicach między ludźmi. Jak tłumaczy uczniom sprawnym trudności występujące $u$ ich niepełnosprawnych kolegów. Czy w swoich wypowiedziach sugeruje, że lepiej być takim, jak inni, czy też podkreśla walory różnorodności. Nauczyciel może pytać uczniów: „Co powinieneś zrobić, jeśli któryś z twoich kolegów popełni błąd?” lub „Jeśli miałbyś jakiś problem, to jakiej pomocy byś potrzebował?" Niewątpliwie, nauczycielowi trudno kształtować u uczniów proinkluzyjne postawy, jeśli sam takich nie prezentuje. Oddziaływanie przez przykład osobisty ma tutaj kluczowe znaczenie. Nauczyciel tolerujący wykluczające zachowania sprawnych uczniów wobec niepełnoprawnych kolegów prawdopodobnie nie poradził sobie jeszcze z własnymi doświadczeniami związanymi z wykluczaniem. Taki nauczyciel powinien dążyć do uświadomienia sobie i przepracowania własnych negatywnych doświadczeń z przeszłości. A jeśli to konieczne, powinien uzyskać specjalistyczną pomoc.

Budowaniu proinkluzyjnej atmosfery w klasie sprzyja eliminowanie wykluczającego języka ${ }^{21}$. Nauczyciel powinien dyskutować z uczniami o obraźliwych słowach kierowanych do tych, którzy pod jakimś względem różnią się od większości osób w klasie. Jeżeli natomiast toleruje naznaczające określenia, przezwiska i obraźliwe komentarze, daje tym, którzy je wypowiadają wyraźny sygnał, że takie zachowania są tolerowane i dopuszczalne. A jeśli próbuje się usprawiedliwiać, mówiąc: „Nic nie poradzisz. Dzieci już takie są", w rzeczywistości ujawnia, że nie chce lub nie potrafi zająć się budowaniem właściwego klimatu społecznego w swojej klasie. Dlatego, wszyscy nauczyciele powinni przeanalizować swoje postawy wobec różnic, a także co na temat różnic chcą przekazać swoim uczniom.

\section{Zakończenie}

Edukacja inkluzyjna jest bardziej skoncentrowana na dziecku, niż na programie nauczania. Opiera się na założeniu, że każde dziecko, również niepełnosprawne, rozwija się we własnym tempie i należy zapewnić takie warunki nauczania, które odpowiadałyby jego potrzebom. Realizacja edu-

${ }^{20}$ N.S. Hall, Creative resource for the anti-bias classroom, Albany 1999, s. 74-79.

${ }^{21}$ M. Sapon-Shevin, Inclusion: A matter of social justice, Educational Leadership, 2003, 2, s. 25-28. 
kacji inkluzyjnej wymaga radykalnych zmian w sposobach myślenia, polityce oświatowej i praktyce szkolnej. Zabiegi dotyczące programu nauczania i organizacji lekcji powinny sprzyjać uczeniu się wszystkich uczniów w klasie. Powinny gwarantować, że wszyscy są traktowani jednakowo, że nie ma w klasie uczniów mniej i bardziej wartościowych. Z pewnością stosowanie rówieśniczego tutoringu sprzyja budowaniu szkolnej społeczności, która nie tylko akceptuje odmienność, ale także ją ceni. Przełomowy w tym procesie jest moment, kiedy klasa zaczyna funkcjonować według następującej zasady: jesteśmy wspólnotą, bierzemy odpowiedzialność jeden za drugiego i nie pozostawiamy bez pomocy tych, którzy jej potrzebują.

\section{BIBLIOGRAFIA}

Aronson E., Terapia dla rywalizującego społeczeństwa, [w:] Psychologia i życie, red. P.G. Zimbardo, F.L. Ruch, Państwowe Wydawnictwo Naukowe, Warszawa 1988.

Deklaracja $z$ Salamanki oraz wytyczne dla działań w zakresie specjalnych potrzeb edukacyjnych, https://rownosc.info/media/uploads/deklaracja_z_salamanki.pdf, [dostęp: 25.10.2018].

Doise W., The development of individual competencies through social interactions, [w:] Children helping children, red. H.C. Foot, M.J. Morgan, R.H. Shute, John Willey \& Sons, New York 1990.

Ginsburg-Block M., J. Fantuzzo J., Reciprocal peer tutoring: An analysis of "teacher" and "student" interactions as a function of training and experience, School Psychology Quarterly, $1997,2$.

Greenwood C.R., Delquadri J.C., Hall R.V., Longitudinal effects of classwide peer tutoring, Journal of Educational Psychology, 1989, 3.

Hall N.S., Creative resource for the anti-bias classroom, Delmar Publishers, Albany 1999.

Melosik Z., Edukacja a stratyfikacja społeczna, [w:] Pedagogika, t. 2, red. Z. Kwieciński, B. Śliwerski, Wydawnictwo Naukowe PWN, Warszawa 2008.

Papuda-Dolińska B., Realizacja koncepcji inkluzyjnej edukacji w szkołach planu jenajskiego doświadczenia holenderskie, [w:] Podmiotowość w edukacji wobec odmienności kulturowych oraz społecznych zróżnicowań, red. N. Starik, A. Zduniak, Wydawnictwo Wyższej Szkoły Bezpieczeństwa, Poznań 2012.

Perret-Clermont A.-N., Social interaction and cognitive development in children, Academic Press, London 1980.

Rainforth B., Kugelmass J.W., Curriculum and instruction for all learners: Blending systematic and constructivist approaches in inclusive elementary schools, Paul Brookes, Baltimore 2003.

Sapon-Shevin M., Because we can change the world: A practical guide to building cooperative, inclusive school communities, Allyn and Bacon, Boston 1999.

Sapon-Shevin M., Inclusion: A matter of social justice, Educational Leadership, 2003, 2.

Sapon-Shevin M., Ayres B., Duncan J., Cooperative learning and inclusion, [w:] Creativity and collaborative learning: A practical guide to empowering students, teachers and families, red. J.S. Thousand, R.A. Villa, A.I. Nevin, Paul Brookes, Baltimore 2002.

Shisler L., Osguthorpe R.T., Eiserman W.D., The effects of reverse-role tutoring on the social acceptance of students with behavioral disorders, Behavioral Disorders 1987, 1. 
Szumski G., Edukacja inkluzyjna - geneza, istota, perspektywy, Kwartalnik Pedagogiczny, 2006, 1.

Thousand J.S., Villa R.A., Nevin A.I., Differentiated instruction: Collaborative planning and teaching for universally designed learning, Corwin Press, Thousand Oaks 2007.

Tudge J., Rogoff B., Wptyw rówieśników na rozwój poznawczy - podejście Piageta i Wygotskiego, [w:] Dziecko wśród rówieśników i dorostych, red. A. Brzezińska, G. Lutomski, B. Smykowski, Zysk i S-ka Wydawnictwo, Poznań 1995.

Twardowski A., Możliwości wykorzystania rówieśniczego tutoringu w edukacji dzieci z niepetnosprawnością intelektualna, Interdyscyplinarne Konteksty Pedagogiki Specjalnej, 2014, 5.

Twardowski A., Rola rówieśniczego tutoringu w rozwijaniu umiejętności komunikacyjnych dzieci przedszkolnych z niepetnosprawnościami, Interdyscyplinarne Konteksty Pedagogiki Specjalnej, 2016, 15.

Wygotski L.S., Wybrane prace psychologiczne, Państwowe Wydawnictwo Naukowe, Warszawa 1971.

Zacharuk T., Edukacja właczająca szansą dla wszystkich uczniów, Meritum. Mazowiecki Kwartalnik Edukacyjny, 2011, 1. 